\title{
Pecan Nut (Carya illionesis) a Potential Future Crop for Enhancing Farmers Profitability in Poonch District of (J\&K), India
}

\author{
Ajay Gupta, Muzaffar Mir, Sudhir Jamwal*, Muneeshwar Sharma and Pawan Sharma
}

Sher-E-Kashmir University of Agricultural Sciences \& Technology-Jammu, India

*Corresponding author

\begin{tabular}{l} 
Ke y w o r d s \\
$\begin{array}{l}\text { Crop based systems, } \\
\text { Horticulture based } \\
\text { enterprises, } \\
\text { Economics }\end{array}$ \\
\hline Article Info \\
$\begin{array}{l}\text { Accepted: } \\
\text { 15 June } 2019 \\
\text { Available Online: } \\
\text { 10 July } 2019\end{array}$ \\
\hline
\end{tabular}

A B S T R A C T
The present study was conducted in Haveli block of Poonch district of Jammu \& Kashmir on prominent crop based systems (Maize-wheat, maize-oats) and horticulture based enterprises (plum orchard, pear orchard, pecan nut orchard and walnut orchard) to study the economics of traditional cropping systems vis-à-vis dominant horticulture based enterprises of the district. Ten progressive farmers following each crop based system viz traditional maize - wheat and maize-oats were randomly identified from five panchayats for the present study. Similarly ten Fruit grower following each dominant horticulture based systems viz. plum orchard, pear orchard, pecan nut orchard and walnut orchard were identified based on bench mark survey conducted by KVK-Poonch. Cost of cultivation and economics of each crop based systems and horticulture based enterprises were calculated to find relative profitability of each system/enterprise. The study revealed that pecan nut orchard exhibited the highest system economics in terms of gross returns (Rs. 6.6 lakhs), net returns (Rs. 5.92 lakhs) with benefit cost ratio of 1:9.79 which was substantially higher as compared to pear orchard (1:6.90) followed by plum orchard (1:6.14) and walnut orchards (1:5.07). However lowest benefit cost ratio was recorded in maize-wheat $(1: 2.53)$.

\section{Introduction}

Due to shrinking land holdings in district Poonch and to double the farmer's income, crop diversification has been recognized as an effective strategy for achieving the objectives of food and nutrition security, income growth, poverty alleviation, employment generation and environmental improvement (Hedge et al., 2003). Horticulture is one of the dominant sectors of Jammu and Kashmir's economy with a yearly turnover of Rs. 1200 crores. It provides direct and indirect employment to over 23 lakh people in state (Darzi, 2016).

Agriculture in Poonch is gradually facing challenges due to production constraints in rainfed areas, stagnant yields, declining income, marketing problems and shrinking land holdings. Integration of fruit trees with agriculture in system or in barren lands can play a vital role in improving system 
productivity, reducing risk in agriculture with additional income and sustainable use of resources. Horticulture is the mainstay of Poonch farmers as lands are slopy and there is limited scope for area expansion in agriculture. Moreover vast land comes under category of barren and uncultivated land which can be used for area expansion in fruit crops due to topography and favourable climatic conditions. District Poonch of Jammu and Kashmir is famous for growing variety of fruits due to favorable soil and climatic conditions. Fruit crops occupy an area of 16351 thousand hectares with annual production of 27000 metric tonnes. Walnut is the most important crop in district followed by apple occupying $42.8 \%$ and $12.98 \%$ of total area under fruit crops (Anonymous, 2016-17). Pear, Peach, Apricot and Plum are also grown on a large scale (presented in Fig. 1). Pecan nut is also an important and niche area crop of the district covering an area of 303 hectares with annual production of 7.26 metric tonnes (Anonymous, 2015-16).

However, percentage of area under Pecan nut trees is very meager as compared to actual land available in the district to be exploited for pecan cultivation. The diverse agro-climatic conditions in the district offer great potential for growing pecan nut at commercial level. Pecan nut is grown within a radius of $0-20$ kms from district headquarters and can be termed as golden crop of the Poonch district due to high market value. Among agriculture based systems, maize-wheat occupies an area of 15000 hectares.

Maize - oats occupying an area of 3000 hectare's is the next prominent crop based systems in Poonch district. Due to poor profitability of traditional crops, people are now shifting to horticulture crops (Kumar, 2015). Horticulture based systems are more remunerative and give higher monetary returns as compared to crop based systems.

\section{Materials and Methods}

The present study was conducted in Haveli block of Poonch district of Jammu \& Kashmir on prominent crop based systems (Maizewheat, maize-oats) and horticulture based enterprises (plum orchard, pear orchard, pecan nut orchard and walnut orchard) to study the economics of traditional cropping systems visà-vis dominant horticulture based enterprises of the district. Ten progressive farmers from each cropping system viz., traditional maize wheat and maize-oats were randomly identified from five panchayats (Nangali, Bhainch, Khanetar, Kankote, Bandichechian). Similarly ten Fruit grower from each dominant horticulture based system viz. plum- orchard, pear- orchard, pecan nut orchard and walnut orchard were identified based on bench mark survey conducted by KVK-Poonch. To analyze the economics of each system/enterprise, it is essential to study the cost of production. Prevailing market prices of different inputs (ploughing, seed, fertilizer, intercultural, plant protection and labor etc.) were taken into consideration for calculating cost of cultivation in field crops whereas for established orchard cost of cultivation included operational costs which was calculated based on managerial costs, expenditure on manuring (farm yard manure and fertilizer), intercultural operations, irrigation, plant protection, pruning, rental value of land and interest for the year under study.

Output prices of commodities prevailing during the year were taken for calculation of gross returns. The net returns were expressed as difference of gross returns and cost of cultivation, whereas benefit cost ratio was calculated by the formula

Benefit Cost ratio $=$-------------- 


\section{Results and Discussion}

Average yield ( $\mathrm{q} / \mathrm{ha})$ cost of cultivation (Rs./ha), net returns (Rs./ha) and benefit cost ratio of different cropping systems (Maizewheat, maize-oats) and horticulture based enterprises (plum orchard, pear orchard, pecan nut orchard and walnut orchard is depicted in table 1 . The study revealed that peacan nut orchard exhibited the highest system economics in terms of gross returns (Rs. 6.6 lakhs/ha), net returns (Rs. 5.92 lakhs/ha) and benefit cost ratio (1:9.79) which was substantially higher as compared to traditional cereal based systems. Plum orchard was the next in terms of economics and exhibited gross returns of Rs. 4.0 lakhs/ha, net returns of Rs. 3.34 lakhs/ha. The higher returns and benefit cost ratio in peacan nut orchard is obviously due to higher market price of peacan nut as compared to walnut. Maize-oats recorded minimum gross returns (Rs. 98750/ha) as well as net returns (Rs. $61750 /$ ha). However lowest benefit cost ratio was recorded in maize-wheat (1:2.53) Lowest returns was recorded in traditional maizewheat and maize-oats based systems as the commodity prices of maize, wheat and fodder oats is substantially low. It was observed that peacan nut crop is highly remunerative among all crop based systems and horticulture based enterprises. Further, peacan nut crop performs best under intermediate zone in Poonch conditions and being drought tolerant, it can be cultivated even if proper irrigation is not available. It also contributes significantly towards farmers' income being a high value crop. Similar results were observed by Kumar (2015) who found that the proportion of income earned from walnut production is considerably more than $70 \%$ in more than $50 \%$ of selected families under study.

Pecan nut is a high market value and can be a future crop in some area in Poonch district due to higher income and net returns from this crop as compared to other horticulture based enterprises and crop based systems. The commercial cultivation of pecans is limited in India. However, due to commercial importance and market demand, the pecan farming has great future in India. It is sold in malls and super markets @ Rs. 800-900/kg whereas in Poonch market the rates of pecan nut varied from Rs. 500-600 per kg during the year 2017-18.

Fig.1 Area in heactres in parenthesis and percentage area under major fruit crops in district

\section{$\%$ area under fruit crops in Poonch district}

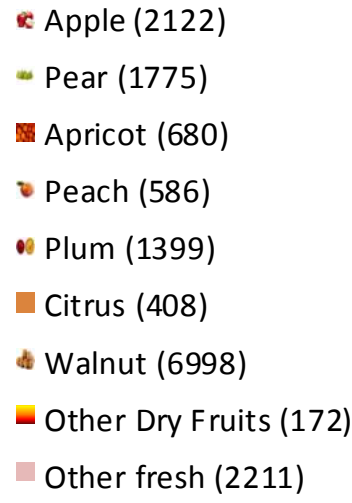

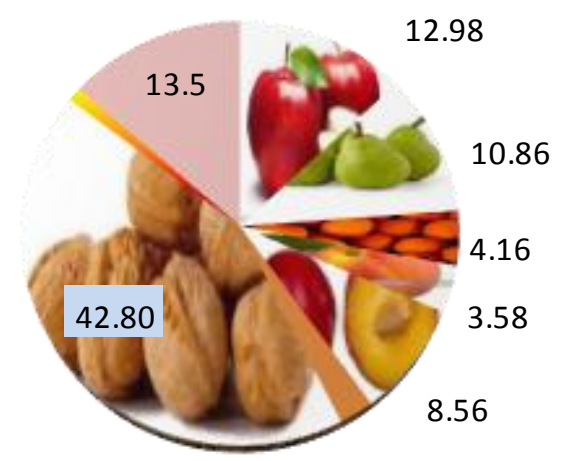


Table.1 System economics of crop based and horticulture based enterprises in terms of gross returns (Rs./ha), net returns (Rs./ha) and benefit cost ratio

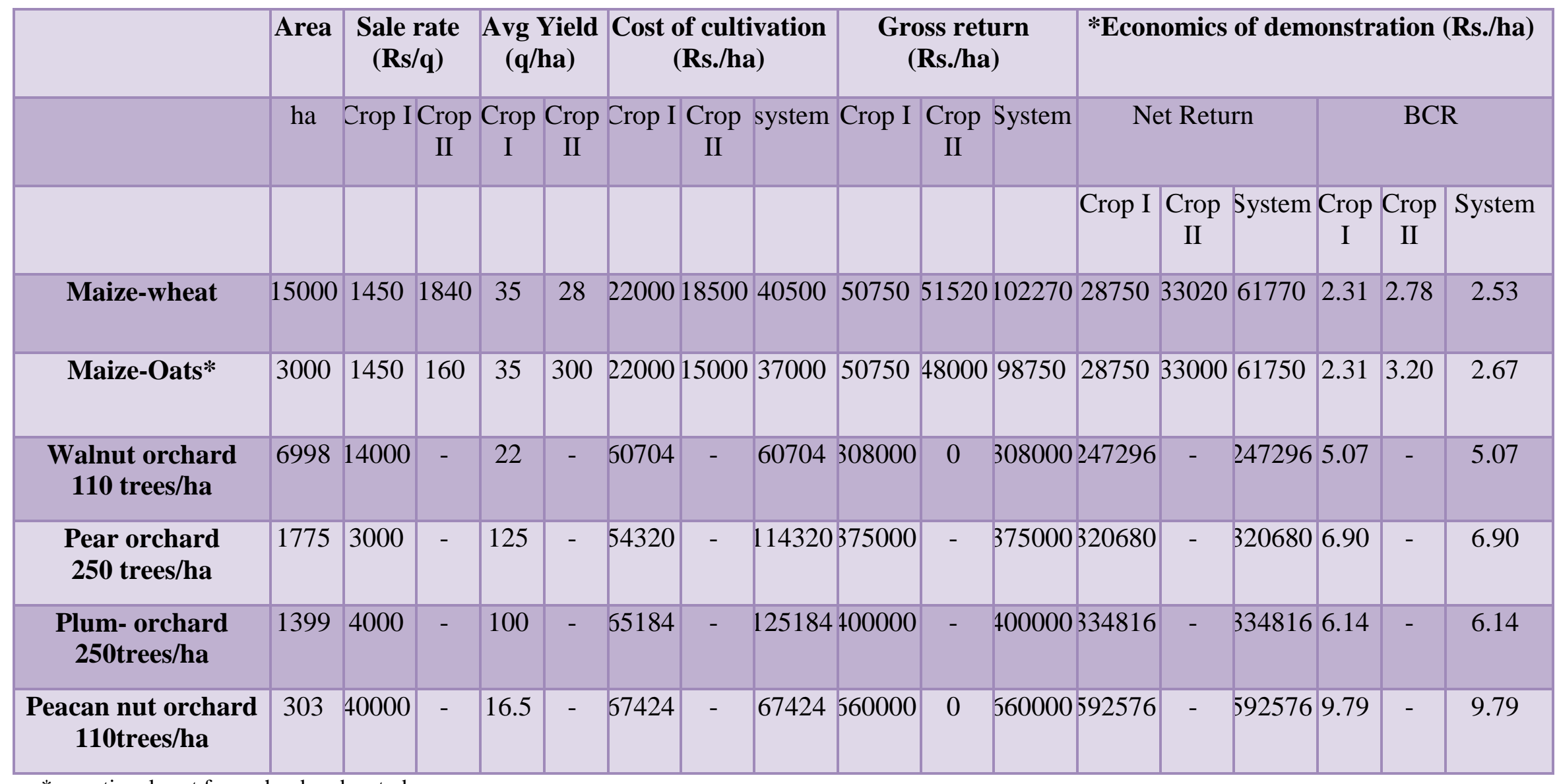

*operational cost for orchard under study

*Green fodder @ Rs. 50,000/ha (Rs. 2500/kanal) 
It was concluded from the present study that Pecan nut cultivation can play a significant role in poverty alleviation of farmers living in hilly and backward areas, as this crop has high remunerative value, market demand, fewer pre and post harvesting losses and also a cash crop.

\section{SWOT analysis}

\section{Strengths}

Favorable climate

High yield

Assured market

Higher economic returns

Fewer losses in pre harvesting and post harvesting stages

Easy to handle and transport

\section{Weaknesses}

Non-availability of quality planting material

Lack of suitable pollinizers

Long juvenile period

Lack of promising varieties

Fragmented, small and marginal land holding with little or no irrigation facilities.

Problems of re-establishment of nursery plants in the orchard.

Hilly terrain and small holding size hinders mechanization.

\section{Opportunities}

Availability of barren and uncultivated land Attractive to Educated and unemployed youth
Limited opportunities in industry offers opportunity for rural youth

\section{Thrust areas}

Area expansion related to economical and consumer oriented diversification to meet the market challenges for earning better returns.

Production of quality planting material of promising varieties

Establishment of new pecan nut orchards

Standardization of production technology of pecan nut

Increase in per unit production by scientific management of orchards and by introduction of improved cultivars.

Rejuvenation of old and senile orchards.

Survey/selection/identification of true to type cultivars of pecan nut for further multiplication.

\section{References}

Anonymous, 2015-16 Department of Horticulture, Jammu, (J\&K).

Anonymous, 2016-17, Digest of Statistics, Directorate of Economics and Statistics Government of Jammu and Kashmir DOS (42)/18

Collingwood, G.H, Brush, W.D and Butches, D (1964). Knowing your tree, $2^{\text {nd }}$ ed. Washington, D.C: American Forestry Association.

Darzi M.I. Horticulture sector towards economic development of Jammu \& Kashmir. International Journal of Multidisciplinary Research and Development 238-240

Green valley Pecan Company. n.d. History of pecans. Green Valley Company. Retrieved April, 13, 2008. 
Kumar, S. 2015. An economic analysis of productivity and of economic dependence of families on walnut cultivation in Jammu and Kashmir,
India. International Journal of Research (IJR) 2: 417-427.

\section{How to cite this article:}

Ajay Gupta, Muzaffar Mir, Sudhir Jamwal, Muneeshwar Sharma and Pawan Sharma. 2019. Pecan Nut (Carya illionesis) a Potential Future Crop for Enhancing Farmers Profitability in Poonch District of (J\&K), India. Int.J.Curr.Microbiol.App.Sci. 8(07): 1907-1912. doi: https://doi.org/10.20546/ijcmas.2019.807.227 